\section{Oxidative Phosphorylation of Guinea-Pig Aorta}

It is an established fact that arterial tissue exhibits a high rate of aerobic glycolysis ${ }^{2}$. As pointed out by LEHNINGER ${ }^{2}$, this might indicate deficiencies in oxidative phosphorylation of the aortic wall. It was therefore considered of interest to measure the oxidative phosphorylation in arterial tissue.

Material and methods. Adult guinea-pigs were sacrificed by bleeding. The aorta was washed, stripped of adhering tissue and homogenized at $0^{\circ} \mathrm{C}$ in $0.5 \mathrm{ml}$ medium $(0.23 \mathrm{M}$ mannitol, $0.07 M$ sucrose, $0.02 M$ Tris buffer, $\mathrm{pH} 7.4$ ) with a Kontes-Duall microhomogenizer. Oxygen uptake was measured with a YSI Model 53 Biological Oxygen Monitor (Yellow Springs Co., Ohio). Organic radiophosphate formation was determined by the method of Nielsen and LeHNinger 4. Radioactive sodium phosphate was obtained from Nuclear Consultants Corp., Chicago, Illinois; it was heated in $1 N \mathrm{HCl}$ for $1 \mathrm{~h}$ at $100^{\circ} \mathrm{C}$ and subsequently neutralized. Countings were made with a GM counter (Tracerlab, Boston, Mass.).

The reaction was carried out in air-saturated medium (final volume $2.25 \mathrm{ml} \mathrm{pH} 7.4$ ) with the following millimolar concentrations: Na-glycylglycine, 15; Na-phosphate, $20\left(1 \mu \mathrm{C} \mathrm{P}^{32}\right.$ ); glucose, $30 ; \mathrm{KCl}, 50 ; \mathrm{MgCl}_{2}, 5$;

Oxygen phosphorylation by aortic tissue

\begin{tabular}{llll}
\hline $\begin{array}{l}\text { Experiment } \\
\text { No. }\end{array}$ & $\begin{array}{l}\mathrm{n} M \text { organic } \\
\mathrm{P}^{32} / \mathrm{mg} \text { wet } \\
\text { tissue }\end{array}$ & $\begin{array}{l}\text { n Atom } \\
\text { oxygen/mg wet } \\
\text { tissue }\end{array}$ & $\begin{array}{l}\mathrm{P} / \mathrm{O} \\
\text { ratio }\end{array}$ \\
\hline 1 & 15.05 & 9.18 & \\
2 & 14.00 & 9.10 & 1.64 \\
3 & 16.65 & 9.80 & 1.54 \\
4 & 11.25 & 6.85 & 1.70 \\
5 & 14.70 & 9.01 & 1.64 \\
\hline
\end{tabular}

Na-ATP, 2.5; cytochrome c, 0.05; Na-pyruvate, 10; Na-malate, 10; Na-EDTA, 1 ; and DPN, 0.5. Homogenate, $0.1 \mathrm{ml}$, equivalent to approximately $20 \mathrm{mg}$ fresh tissue, was added. After $4 \mathrm{~min}$ equilibration at $30^{\circ} \mathrm{C}$ the reaction was started by addition of $2 \mathrm{mg}$ hexokinase (Sigma Type V) and readings of oxygen consumption were begun after $30 \mathrm{sec}$. The reaction was stopped after $30 \mathrm{~min}$ by addition of $0.1 \mathrm{ml}$ concentrated TCA to a 1.0 $\mathrm{ml}$ aliquot. After centrifugation, organic phosphates were quantitatively extracted from the supernatant and the radioactivity of these compounds determined.

Results. In the Table the results of the experimental studies are presented, which show a notable rate of oxidative phosphorylation displayed by guinea-pig aortic homogenates in the presence of pyruvate and malate substrates. This confirms the findings recorded by WoLLEMANN and KOCSAR ${ }^{5}$ in experiments with rat aortic tissue. These observations are of interest in view of the low Pasteur effect ${ }^{2}$ in arterial tissue.

Zusammenfassung. Bei der Untersuchung von AortaHomogenaten von Meerschweinchen wurde ein hoher P/O Quotient für die oxydative Phosphorylierung gefunden.

E. RITZ and J. E. KIRK

Washington University School of Medicine, St. Louis (Missouri, USA), July 29, 1966.

1 This work was supported by Public Health Scrvice Gran. No. HE-00891.

2 J. E. Kink, P. G. EFfersol, and S. P. Chang, J. Geront. 9, 10 (1954).

3 A. L. LeHninger, in The Arterial Wall (Ed. A. I. LANsinc; Williams and Wilkins, Baltimore 1959).

4 S. O. Nielsen and A. L. Lehninger, J. biol. Chem. 215, 555 (1955).

3. Wollemann and L. Kocsar, J. Atheroscler. Res. 4, 367 (1964).

\section{Uptake of Labelled DNA by Isolated Perfused Organs}

Many cells are capable of taking up highly polymerized DNA and of retaining it for some time ${ }^{1}$. This phenomenon has been demonstrated in plants ${ }^{2}$, in cells, in tissue culture $^{3}$, and in intact mice ${ }^{1,4}$. It is, however, difficult in the intact animal to distinguish the contributions of different organs to the uptake and the breakdown of DNA. The technique of perfusing isolated organs appeared, therefore, particularly suitable for the study of the uptake of DNA and its degradation in a given mammalian organ. By changing the perfusion liquid, after uptake has taken place, it is, furthermore, possible to determine whether the DNA is retained in the tissue.

Methods. Perfusion of the isolated liver of rats was carried out as described elsewhere $5,6,9$. Fresh, heparinized rat blood diluted with $1 / 3$ volume of Ringer solution was used as perfusion medium. In some experiments, the perfusion medium containing the active material was replaced during perfusion with non-radioactive perfusate.
This washing fluid was either perfused only once or recycled continuously through the organ. The perfusion apparatus was set up in such a way that this change was possible without appreciable mixing between the two fluids and without disturbing the perfusion.

Labelled DNA was prepared from $E$. coli strain CR34 (thymine less), according to the method of MARMUR ${ }^{7}$ using $\mathrm{H}^{3}$-thymidine or $\mathrm{P}^{94}-\mathrm{O} 4$ as precursor. The specific activity of the DNA thus obtained was $1 \mathrm{mCi} / \mathrm{mg}$ for $\mathrm{H}^{\mathrm{s}}$ DNA or about $0.01 \mathrm{mCi} / \mathrm{mg}$ for P $^{92}-\mathrm{DNA}$.

The samples taken from the organs during perfusion were homogenized in $40 \mathrm{vol}$ of water, and $50 \lambda$ of homogenate or perfusate were used for the chromatographic fractionation by centrifugation on DEAE-paper pulp according to procedures published earlier ${ }^{1,8}$. 6 different eluants are used for the elution. Fraction 1 (average molecular weight 200 ) is eluted with $0.02 M$ phosphate buffer $\mathrm{pH} 7$ ( $\mathrm{P}$ buffer), and fraction 2 (average molecular weight 2000) with $0.14 \mathrm{M} \mathrm{NaCl}$ in $\mathrm{P}$ buffer. These ? fractions are acid soluble. Elution is then continued with $0.5 \mathrm{M} \mathrm{NaCl}$ in $\mathrm{P}$ buffer (fraction 3 average molecular 